\title{
Introduction: Religion and Freedom of Expression
}

\author{
Peter Jones
}

Published online: 26 January 2011

(C) Springer Science+Business Media B.V. 2011

Tensions between religion and freedom of expression have a long pedigree. Given the central place that religious faith has occupied in the history of humanity and given the special status humanity has ascribed to the sacred and the divine, it could hardly have been otherwise. Contemporary controversies concerning the relative claims of religion and free expression might therefore be seen as no more than the latest episodes in an argument that has been conducted for two or more millennia. But the history of that argument is a changing history and its present character differs from its past. While in some societies the shielding of religion from free expression continues to be defended as a means of maintaining truth and preventing its corruption, that form of defence has been largely abandoned in western societies. In those societies, religious diversity is now accepted as a legitimate state of affairs as well as a matter of fact, so that, at least in public argument, no denomination and no faith can claim protection simply in virtue of the truth of its beliefs. As the articles that make up this collection indicate, arguments about faith and free expression now pivot on different sorts of concern, such as the recognition due to people's identities, the prevention of offence, insult and hatred, and the maintenance of public order and social cohesion. Appeals to the truth and its promotion are now more likely to come from those who want religion to feel the full force of free expression.

Arguments about the respective claims of religion and free expression are also now conducted in a world in which there is a large measure of 'unbelief', which encompasses a wide variety of positions from dogmatic atheism to mere failure to be engaged by religion. They take place too in a world in which we are used to distinguishing between the proper spheres of the religious and the secular. Against that background, it is easy to gain the impression that the battle lines in arguments

P. Jones $(\bowtie)$

School of Geography, Politics and Sociology,

Newcastle University, Newcastle upon Tyne NE1 7RU, UK

e-mail: p.n.jones@ncl.ac.uk 
over religion and expression are drawn between religion's proponents and its opponents. The religious uphold the claims of faith against intemperate abusers, whilst their opponents champion the cause freedom of expression against those who would immure religious belief from critical comment. However, that is altogether too simple. One does not need to have a religious faith or to be of a particular faith to reject an 'anything goes' approach to people's use of expression in relation to religion. Even more obviously, a religious faith is no barrier to recognizing the case for free expression. Indeed, the religious have an obvious interest in being free to express their faith and to express their rejection of challenges to it. Some religious groups were, for example, active opponents of measures introduced by the British Government to proscribe incitement to religious hatred, fearing that the new law would inhibit robust expression of their own beliefs and their robust criticism of the beliefs of others.

The issue of free expression on religious matters relates then to two sorts of freedom: the freedom to express a belief or faith and the freedom to express a view about a belief or faith, such as a view that challenges, criticizes or ridicules it. If we think of recent high-profile controversies about free expression and faith-such as the Rushdie Affair or the Danish cartoons or the row over Jerry Springer: the Opera-these seem to be most obviously controversies that concern the second of these freedoms. They are not always cases in which the offending expressions are meant to attack or criticize or comment in some other negative fashion on the beliefs or faith at issue. Sometimes they simply treat religious subjects in ways that others find improper or inappropriate. It is these sorts of case that are most readily represented as conflicts between the claims of religion and those of free expression.

If we turn to expressions of religious faith, these too can still provoke public controversy. Consider, for example, expressions of faith that challenge gender equality or the acceptability of homosexual conduct; or consider the way in which the development of Islamic terrorism now confronts governments with the question of how far they should curtail expressions of religious belief that might encourage violence. However, in the everyday world, controversies over expressions of religious faith perhaps now arise more frequently in relation to what the faithful do rather than what they say. They relate, that is, to practices that express religious faith and to how far societies should permit or facilitate those practices. These are typically conceived as issues of accommodation-issues concerning the extent to which societies should take special steps to accommodate religious practices because they are religious practices. These issues have arisen largely, though not wholly, from the increasingly multi-faith character of western societies. In fact, whether they should really be conceived as issues of 'accommodation' is sometimes moot. If, for example, a society allows Muslim women to wear the burka, is it accommodating a practice or merely not depriving would-be burka wearers of a freedom that is enjoyed by the population at large, the freedom to dress as they please; and if conversely it bans the burka, is it merely failing to accommodate or is it visiting a special restriction upon a group?

However, many issues of 'accommodation' are certainly properly so described. They make special provision for practices for which there would no such provision were they not religiously-based. That is most conspicuous in the case of exemptions, 
such as those enjoyed in Britain by Jews and Muslims that enable them to practise religious slaughter, and by Sikhs entitling them to carry the kirpan in public and to ride a motorcycle without wearing a crash helmet, provided they wear a turban. Much more generally, discrimination legislation in Britain now obliges employers and the providers of goods and services to dispense with a provision, criterion or practice (PCP) if it has the effect of disadvantaging a particular religious group, even though that effect may be entirely incidental. In effect, this prohibition on 'indirect' discrimination requires employers and providers to accommodate the religious practices of their employees and customers, unless they can show that their PCP is 'a proportionate means to a legitimate aim'. Moreover, even discrimination legislation includes exemptions that give religious organizations limited entitlements to discriminate on grounds of gender or sexuality in employment and in the provision of goods and services.

What can justify this special treatment of practices that express religious belief and how far should it extend? Raymond Plant addresses those questions. Much contemporary thinking on them stresses the significance of 'identity' and the need for particular groups to have their identities 'recognised' in their society's institutional and legal arrangements. Plant, however, points to a number of difficulties that beset the notion of religious identity and its recognition by a society. He also questions the ease with which identity theorists close the fact/value gap and move from asserting the fact of identity to constructing obligations for others in respect of that identity. He suggests that it is more profitable to approach the issue of expressive religious practices through the harm principle, so that people are free to engage in religious practices subject only to the condition that their practice does not harm others. 'Harm', however, should be taken to include the undermining of other people's equal status as citizens, so that religious practices cannot trump the demands of civic equality.

Maleiha Malik is also examines claims of religious expression. She focuses on the tension between the claims of religious belief and those of sexuality. Religion and sexual orientation have both been the subjects of discrimination legislation in Britain and elsewhere; both have also been the subjects of hate speech legislation; and the protections afforded to both have been defended in the name of liberty and equality. Yet, given the disapproval with which many religious faiths regard homosexual conduct, the claims of religion and sexuality as 'protected characteristics' have inevitably come into conflict. Malik examines how legislators and courts in Britain, the US and Canada have sought to deal with the competing claims of religion and sexuality. These have included granting the religious exemptions from sexual orientation regulations; using a distinction between belief and conduct to give greater freedom to the holding and articulation of beliefs hostile to homosexuality than to conduct based upon those beliefs; and use of private/public distinctions to permit discrimination on grounds of sexuality in an association's private, but not in its public, activities. Malik herself argues that there is no easy legal solution to conflicts between the claims of religion and sexuality, particularly given the lack of social consensus on the merits of those claims, and suggests that legal measures need to be supplemented by a variety of non-legal measures designed to diffuse or resolve conflict without resort to law. 
If we turn from expressions of to expressions about religious faith, these also sometimes take the form of expressive acts that we would not normally describe as 'speech'. Consider, for example, the (unexecuted) plan of the Florida pastor, Terry Jones, to burn copies of the Koran on the anniversary of the 9/11 attack on the Twin Towers in New York (although Jones would no doubt say that his planned conflagration would have been an expression of his Christian faith as well a comment on Islam). But it is perhaps more common for controversial expressions about religious faith to take the form of 'speech' broadly construed, whether this be oral or written or pictorial (for example the Danish cartoons of Mohammed). Even so, cases like Jerry Springer: the Opera or Martin Scorsese's film, The Last Temptation of Christ, or the artwork Piss Christ, while clearly forms of 'expression', do not lend themselves easily to a speech/act distinction.

Until recently, the most conspicuous legal limit in Britain on freedom of expression in relation to religion was the common law of blasphemy. That law had been widely supposed to be obsolete in the second half of the twentieth century until in 1977 Mary Whitehouse brought a successful private prosecution for blasphemy against the editor and publishers of Gay News. The survival of blasphemy as a legal offence in a modern liberal society seemed to many an anachronism. It was also inequitable since it protected only Christianity and possibly only Anglicanism. The obvious options were either abolition of the law or the extension of its protection to non-Christian faiths. In fact, governments fought shy of either reform until 2008 when the blasphemy law was abolished following the introduction of a new offence of incitement to religious hatred in 2006.

Britain's substitution of a law on religious hatred for a law on blasphemy reflected a more general pattern of change in religious legislation in many other European countries. Outlawing incitement to religious hatred seems altogether more appropriate for a liberal democratic society. For one thing, hate speech laws typically afford protection to people not just in relation to religion but also in respect of several other characteristics, such as race and sexual orientation, and they can protect unbelievers as well as believers. To that extent they privilege neither religion nor the religious after the fashion of blasphemy laws. In addition, the object of their protection is people-people who hold beliefs rather than the beliefs that they hold-and nowadays that would seem a much more acceptable purpose for law. However, while blasphemy and religious hatred laws may differ in conception, the big question is whether they will be so very different in effect. Can we, in reality, protect the religious without simultaneously protecting their beliefs in ways and to extents that will silence critical treatments of religion unacceptably?

Eric Barendt gives a sceptical answer to that question. He identifies a number of ways in which race and religion differ, so that there can be no simple equivalence between the case for proscribing incitement to racial hatred and that for proscribing incitement to religious hatred. Like Plant, he also identifies several difficulties in the notion and normative thrust of religious identity. But his principal claim is that, if a religious hatred law is to add anything to the protection the religious already enjoy under other legislation (e.g. against incitement to violence), this cannot avoid the effect of protecting their beliefs from abuse and criticism. The distinction that was central to the Government's defence of its Bill—that it protected religious groups but 
not their beliefs and so posed no threat to legitimate freedom of expression-is not sustainable. It is as well therefore that the House of Lords diluted the Government's Bill and added to it a clause directly protecting freedom of expression.

Barendt bolsters his argument by pointing out how the European Court of Human Rights (ECtHR), in upholding the claims of religion to limit freedom of expression, has been unable to protect the religious without protecting their beliefs. The European Convention on Human Rights (ECHR) includes rights to both freedom of religion (Article 9) and freedom of expression (Article 10). How far do those two Convention rights constitute competing claims and how should they be reconciled when they do compete? Ian Leigh argues that the answers to those questions implicit in decisions of the ECtHR have been both inconsistent and unsatisfactory. The Court has added its own embellishments to Article 9 in ways that justify a degree of protection for religious belief that is not warranted by the actual text of the Article. It has used the doctrine of 'margin of appreciation' to sanction different forms and degrees of restriction in different countries; and its use of a hierarchy of forms of speech has led it to undervalue certain forms of expression, particularly artistic expression, and to treat inconsistently different sorts of critical and satirical attack on religion. In general, the Court has read into Article 9 a degree of protection against anti-religious expression that the freedoms enunciated in the Article do not warrant. The scope for genuine conflict between freedom of expression and freedom of religion in the ECHR is, Leigh concludes, very much less than the reasonings of the ECtHR would have us believe.

In my own contribution to this issue, I examine the appeal to 'offensiveness' as a reason for limiting freedom of expression. Being offended has become increasingly fashionable, as has the supposition that the offended are, merely in virtue of being offended, entitled to veto what offends them. During the nineteenth century, the common law of blasphemy came to be defined with reference to what offended Christian believers. Offensiveness does not have a similar place in religious hatred legislation, but, if Barendt is right, it could still figure in the use to which that legislation is put and, as Leigh indicates, it is still a relevant consideration for the ECtHR. In popular and academic discussions of religion and the limits of free expression, appeals to offensiveness are ubiquitous. I give an explanation of why complaints formulated in the language of offence are so common in a context of diverse and conflicting beliefs, but I also question whether 'being offended' should constitute a significant reason for others and whether those who complain of offence really mean that to signify the substance of their complaint. In addition, making offence the salient consideration has unfortunate implications for both parties to the dispute. I propose a principle of respect for beliefs as a differently based and more plausible reason for restraining the treatment we mete out to other's beliefs, but one that cannot override freedom of expression that has a serious purpose.

I also suggest that 'respect for beliefs' is more appropriate as a principle that should influence our conduct within law rather than one that should dictate the content of law. Issues of freedom of expression arise, perhaps especially in relation to religion, as issues of how we should conduct ourselves within the law and not only as issues of what the law should be. That non-legal domain and the practice of self-censorship is John Horton's concern. Given the significance of self-censorship, 
both as an idea and a phenomenon, for issues of free expression, it is remarkable, as Horton notes, that it has receive so little attention from political philosophers. Horton explores the lineaments of the concept of self-censorship and, in particular, the complexities affecting how far the censoring 'self' is an autonomous self and how far it is merely an instrument of external pressures, in which case its authenticity as selfcensorship (in one of its senses) is brought into doubt. That distinction relates to, but is not wholly congruent with, the equally important question of when we should applaud, and when we should deprecate, self-censorship. We might, for example, view one instance of self-censorship as laudable sensitivity for the feelings of others and another as culpable cowardice or self-serving dishonesty. Horton exposes the tensions and ambivalences inherent in the notion of self-censorship and in our appraisals of it.

Horton's article signals an important feature of the debate about freedom of expression in general and its bearing on religious beliefs and allegiances in particular. That debate is sometimes conducted as though it were simply a question of establishing what people ought or ought not to say, which in turn should determine what they should be legally free or unfree to say. But that is too simple in at least one respect. For all sorts of reason, we do not think that our conduct should be restrained only by law; because, for example, resort to law is cumbersome and expensive, because we are unwilling to allow others, including 'official' others, to be the arbiters of all that we should or should not do, and because general rules are not equal to the intricacies of conduct and context that bear upon appropriate behaviour. Thus, while the argument about the interplay between religious belief and freedom of expression must be in part argument about the proper content of law, it must also be about acceptable conduct within the law. For publishers, the media and all sorts of public organizations, as well as for private individuals, issues of nonlegal restraint are nowadays likely to be no less significant than those relating to law and its limits.

Acknowledgments The papers that make up this special issue were originally presented to a meeting of the Workshop on the Role of the State in a Multi-Faith Society, co-organised by Peter Jones and Stuart White, which met during 2008. The Workshop formed part of the AHRC/ESRC Programme on Religion and Society. We are very grateful to all who participated in the Workshop's proceedings and to the AHRC and ESRC for their support. 